\title{
Grudzień 1970
}

Ilekroć stoję pod gdańskim pomnikiem Trzech Krzyży, tylekroć myślę z podziwem i współczuciem o tych, którzy zginęli w zimowych dniach Grudnia 1970 i Grudnia 1981. Myślę o nich z podziwem i współczuciem, bo sam nigdy nie byłem do nich podobny - i dlatego żyję i mówię w tej chwili do Państwa to, co mówię. Gdybym był do nich podobny, już bym nie żył i z moich ust nie padłoby nawet jedno słowo. Oni byli odważni jak bohaterowie Przesłania Pana Cogito Zbigniewa Herberta. Ilu ich było? Odważnych zawsze jest tylko garstka.

15 grudnia 1970 roku znalazłem się przypadkiem na ulicy Szerokiej w Gdańsku. Od strony skrzyżowania na Hucisku dobiegały okrzyki wzburzonego tłumu, który gromadził się pod Komitetem Wojewódzkim. Tam, za Huciskiem, huczał wzburzony tłum, co jakiś czas wybuchały granaty z gazem łzawiącym, wyły karetki pogotowia, odwożące rannych do szpitali, tu, na ulicy Szerokiej - jakieś paręset kroków od gmachu Komitetu Wojewódzkiego - panował spokój. Przez okna szyb wystawowych widziałem, co działo się w sklepach. W narożnym, ze słodyczami, stała kolejka po toruńskie pierniki, które właśnie dowieźli, w sklepie odzieżowym kobiety przymierzały garsonki i płaszcze, chodnikiem szła kobieta ze sklepu spożywczego, niosła w siatce bułki, warzywa, jakieś owoce, chyba jabłka.

Ja sam nie dołączyłem do tłumu pod Komitetem. Pamiętałem słowa 0jca: nigdy się w nic nie mieszaj, nie bierz udziału w niczym, jak zobaczysz tłum, szybko wracaj do domu, nigdy nie wypowiadaj się publicznie na żaden temat, żyj tak, by nikt nie wiedział, że żyjesz, nie wyróżniaj się niczym spośród „zwykłych ludzi”, nie wierz w żadne rewolucje i przełomy, zawsze będzie to samo, jedni odchodzą, drudzy przychodzą, ale ludzka podłość jest zawsze ta sama, nie daj się nabrać na żadne nadzieje, nie wierz w żadne zmiany, tak jak jest, będzie zawsze, sprytni, obrotni, przebiegli, bezwzględni zawsze wypłyną na wierzch, oni zawsze sobie poradzą, czy taki ustrój, czy taki, wykorzystają cię, zostawią na lodzie, ty się będziesz narażał, zginiesz albo zostaniesz kaleką na całe życie, postawią ci pomnik, ale nic się nie zmieni, oni zawsze będą na wierzchu, oni zawsze sobie poradzą, obojętnie, co będzie.

Powie ktoś, że mój ojciec był tchórzem. Możliwe. Ale wszystkich tych mądrości mój ojciec nauczył się w Wilnie podczas trzech okupacji tego miasta, gdy krwawe

\section{STEFAN CHWIN}

Esej powstał na prośbę Europejskiego Centrum Solidarności i wygłoszony został przez prof. Stefana Chwina podczas uroczystości Epitafium pamięci ofiar Grudnia '70 w 35. rocznicę odsłonięcia pomnika Poległych Stoczniowców 1970, która odbyła się 16 grudnia 2015 roku w ogrodzie zimowym Europejskiego Centrum Solidarności w Gdańsku. 
polowania na Polaków urządzali sobie litewscy szaulisi, gestapo i NKWD. Widział tam na własne oczy sprytnych, obrotnych, przebiegłych, którzy nawet w najokropniejszych warunkach potrafili wypłynąć na wierzch. Wiedział, że oni są niezmienni, że oni są prawdziwą solą ziemi, tej ziemi, dlatego bardzo chciał, żebym ja nie był bohaterem, tylko żebym przeżył, tak jak jemu udało się cudem przeżyć trzy okupacje Wilna, nie trafić przed pluton egzekucyjny NKWD albo na Sybir, tylko dlatego że nie brał udziału w niczym, żył niewidoczny w masie niewidocznych „zwykłych ludzi”. I tylko dlatego, że on tak żył, ja dzisiaj żyję, oddycham i mogę stanąć tu przed Państwem i mówić to, co mówię.

Ilu Polaków wyszło na ulice w całej Polsce w Grudniu '70 i Grudniu '81? Sto tysięcy, dwieście, trzysta? Nawet jeśli tyle, to w porównaniu z całym narodem, który liczył wtedy ponad 30 milionów ludzi, była to garstka. Bo zawsze buntowała się, biła i ginęła garstka. Wstępowała do legionów garstka. Robiła powstanie warszawskie garstka, dziesięć tysięcy dziewcząt i chłopców w mieście, które liczyło ponad półtora miliona mieszkańców. Wolne Związki Zawodowe zakładała w Gdańsku garstka. Komitet Obrony Robotników zakładała garstka. Co robiła reszta? Reszta robiła to, co zawsze. Szła do pracy, wracała z pracy, jadła i spała. Reszta się przyglądała, co będzie dalej, kto wygra, a kto przegra, i zastanawiała się, po której stanąć stronie, jak wygrają ci albo tamci. Ta reszta to nie były setki tysięcy, które wyszły na ulice, to były dziesiątki milionów „zwykłych Polaków”, którzy nigdy nie podnieśli nawet jednego palca na komunizm, w nic się nie mieszali, a gdy na ulicy zobaczyli tłum, szybko wracali do domu, chociaż po cichu komunizm przeklinali.

A ci, którzy zginęli? Wedle rodziny Jerzy Matelski, stoczniowiec i członek Polskiej Zjednoczonej Partii Robotniczej, został zabity na dachu budynku, gdy ściągał spod ostrzału kolegę. Ale wedle innej relacji Matelski zginął 16 grudnia 1970 w bramie nr 2 Stoczni Gdańskiej. Wedle raportów SB, gdy dzień po wcześniejszych zajściach na ulicach Gdańska kordon żołnierzy i pojazdów wojskowych zablokował wyjście ze stoczni na miasto, Matelski mimo komunikatów ostrzegawczych nadawanych przez wojsko - z kilkoma osobami wyszedł przed stoczniową bramę. Żołnierze, widząc zbliżającą się grupę, w obawie, że stoczniowcy chcą przejąć pojazdy wojskowe, otworzyli ogień. Nie wiadomo, czy strzelali do robotników, czy Matelski zginął od rykoszetu. Możliwe też - jak mówią jeszcze inne relacje - że strzelano z przelatującego helikoptera albo zabił go z ukrycia odległy snajper.

Jeszcze inna relacja podkreślała, że Matelski wcale nie wyszedł przed bramę, tylko został wypchnięty poza teren stoczni przez liczący osiemset osób tłum robotników, napierający z wnętrza na stoczniowe ogrodzenie, i nie mógł się już cofnąć. Tylko akt zgonu, wystawiony przez lekarza, nie pozostawiał żadnych wątpliwości. Przestrzał klatki piersiowej, połączony z uszkodzeniem worka osierdziowego, rozerwaniem tętnicy szyjnej, aorty i lewego płuca.

Okoliczności śmierci drugiego stoczniowca, który zginął razem z Matelskim pod bramą nr 2 Stoczni, Stefana Mosiewicza, były przez świadków przedstawiane jeszcze inaczej. Wedle zdjęcia, które $\mathrm{z}$ okna zrobił mieszkaniec wieżowca przy ulicy Doki, 16 grudnia przed bramą stoczni stały dwa czołgi, transporter opancerzony i kilku żołnierzy (prawdopodobnie z Obrony Terytorialnej i 55 Dywizji Zmechanizowanej), zwróconych twarzami w stronę bramy stoczni. Obok nich na ziemi został ustawiony karabin maszynowy. Po tym, jak żołnierze oddali serię w kierunku ludzi wychodzących z bramy, stali sobie spokojnie, rozmawiali, palili papierosy, jakby nic się nie stało. Wedle relacji jednego $\mathrm{z}$ dowódców, pułkownika WP Eugeniusza Stefaniaka, wojsko najpierw cofnęło czołgi od bramy stoczni, co stoczniowcy źle zrozumieli i - ośmieleni - ruszyli do przodu, jakby chcieli przejść przez kordon wojska. Jeden z żołnierzy z obsługi czołgu nie wytrzymał nerwowo i puścił serię z karabinu maszynowego. Inni żołnierze na widok zbliżającej się grupy zaczęli strzelać na komendę "0gnia!". 
Nie wiadomo, czy były to strzały ostrzegawcze, czy do robotników. Czy jednak możemy tej relacji ufać? Inne relacje mówiły, że żołnierze strzelali pod nogi stoczniowców, w bruk i ponad głowami, ale Mosiewicz został trafiony w głowę. Zginął od rykoszetu? I z czyjej właściwie broni? Każdy z naocznych świadków przysięga, że mówi prawdę, i każdy mówi co innego. Więc czy kiedykolwiek dowiemy się, jak było naprawdę? Historycy wątpią, by było to możliwe.

Pamiętam, jak w Grudniu 1970 polskie kobiety podchodziły do czołgów stojących na ulicach Gdańska, patrzyły na żołnierzy, których głowy wystawały z czołgowych włazów, i mówiły: „Te, odezwij się, czyś ty Polak czy Rusek?". Ale twarze żołnierzy nie wyrażały nic. Milczały jak zaklęte. Te kobiety za wszelką cenę chciały uwierzyć, że Grudzień rozbili czołgami Rosjanie przebrani za Polaków, ale historycy, niestety, ustalili, że to nie byli żadni Rosjanie. To byli polscy chłopcy w polskich mundurach. I to był fakt podstawowy: ani w Grudniu 1970, ani w Grudniu 1981 nie znalazł się nawet jeden polski żołnierz, który by powiedział do polskiego oficera: Odmawiam wykonania rozkazu. Ja tego łajdackiego rozkazu nie wykonam. Nie wyjadę czołgiem na ulice, by gąsienicami rozwalać bramę stoczni i strzelać do robotników. Nawet jeden taki polski żołnierz się nie znalazł.

Chciałbym, żeby polska kinematografia zrobiła film o polskim chłopcu z Grójca, Zielonej Góry czy Tomaszowa, który w listopadzie 1970 roku dostaje kartę mobilizacyjną, idzie do wojska, zostaje dowódcą czołgu w jednostce w Braniewie, a potem razem ze swoim kolegami, polskimi żołnierzami, w czołgu PT 76 wjeżdża 15 grudnia na ulice Gdańska pod płonący Komitet Wojewódzki. Ten chłopiec mógłby najpierw pracować w Stoczni Gdańskiej i nazywać się na przykład Birkut, ale mógłby się też nazywać na przykład Jan Kowalski albo Stefan Chwin. Co zrobiłby ten polski chłopiec w czołgu PT 76 na ulicach Gdańska, gdyby dostał od polskich oficerów rozkaz strzelania do tłumu demonstrujących stoczniowców pod płonącym Komitetem
Wojewódzkim? Film o takim chłopcu to byłby film o prawdziwej historii Polaków i może byłby równie ważny, a może ważniejszy od Człowieka $z$ marmuru i Człowieka z żelaza, a nawet od filmu o rotmistrzu Pileckim, bo opowiadałby o losie dziesiątków tysięcy polskich chłopców, którzy znaleźli się w czołgach na ulicach Gdańska, Elbląga i Szczecina. Bo to były dziesiątki tysięcy polskich chłopców, osiemnasto-, dziewiętnastoletnich poborowych z polskich miast, miasteczek i wsi, Polaków, katolików, rolników i robotników.

Więc w całym polskim wojsku nie znalazł się nawet jeden żołnierz, który by powiedział: Nie, nie wyjadę na miasto, nie będę strzelał do robotników? Chociaż może to nie jest zupełna prawda. W lipcu 1982 roku koło poligonu wojskowego nad jeziorem Jasień pod Gdańskiem zobaczyłem oddział żołnierzy na ćwiczeniach. Był upał, trzydzieści stopni. Oni byli w pełnych mundurach, w hełmach, na twarze mieli naciągnięte gumowe maski przeciwgazowe, na ramionach ciężkie plecaki. Zmuszano ich do biegania. Kilku przewróciło się i straciło przytomność. Potem "ćwiczenia" przerwano, bo kiedy jeden $\mathrm{z}$ nich zerwał $\mathrm{z}$ twarzy maskę gazową, z nosa i ust buchnęła mu krew. Kiedy do nich podszedłem, powiedzieli, że są z jednostki karnej. Za co tam trafili? 12 grudnia 1981 roku odmówili wyjścia z koszar w Elblągu. Tak mi powiedział jeden z nich. Mogli mówić o szczęściu, że nie dostali od razu w czapę, bo obowiązywało prawo stanu wojennego. Trafili na reedukację do karnej.

Dla mnie prawdziwymi bohaterami Grudnia obok tych, którzy odważyli się zrobić strajk w Stoczni Gdańskiej, była właśnie garstka tych polskich chłopców z Elbląga. I to pomnik tych chłopców powinien stanąć obok pomnika Poległych Stoczniowców. Tych kilkudziesięciu chłopców z Elbląga, którzy zsiniałymi z wysiłku palcami trzymali się żelaznych łóżek, kiedy ich z koszarowej sali wywlekała siłą wojskowa żandarmeria i ładowała na ciężarówki. Ale czy władze niepodległej Polski odznaczyłyby tych polskich chłopców, tych polskich żołnierzy za odwagę i bohaterstwo? Polski żołnierz, 
który z patriotycznych powodów odmawia wykonania rozkazu swojego przełożonego, to jest niestety trefny towar dla każdej władzy, obojętne, czy to jest władza komunistyczna czy niekomunistyczna. Każdy oficer wychowawczy wie, że o takim chłopcu nie wolno mówić żołnierzom polskiej armii, bo to jest zły przykład. Każdy nauczyciel też to wie. Więc ci chłopcy żadnego pomnika nie dostaną na pewno nigdy i żadnego odznaczenia też im nikt nie wręczy. Zresztą nie wiadomo, może to, co usłyszałem na gdańskim poligonie nad jeziorem Jasień w upalny dzień lipca 1982 roku, to była tylko jedna z polskich legend i w rzeczywistości takich chłopców w ogóle nie było. W żadnym ze źródeł historycznych nie trafiłem na ślad ich istnienia.

Ale ja ich widzę, widzę, jak są szarpani przez żandarmerię wojskową, jak są odrywani siłą od żelaznych koszarowych łóżek, jak są bici pałkami po zsiniałych palcach, jak są popychani, kopani przez innych polskich żołnierzy, a potem jak są dręczeni przez polskich oficerów w karnej kompanii, i chciałbym, żeby powstał film o nich, o tych polskich chłopcach, ale taki film na sto procent nigdy w Polsce nie powstanie, bo na taki film nikt nie da żadnych pieniędzy, a poza tym, czy naród polski chciałby pójść do kina na taki film, o takich polskich żołnierzach, którzy z powodów patriotycznych mówią do swojego przełożonego „nie!" i drogo za to płacą?

A poza tym, czy gdyby w Grudniu 1981 i Grudniu 1970 znalazło się w Polsce więcej takich żołnierzy, jak ci z chłopcy Elbląga, w Gdańsku byłoby mniej zabitych i wtedy na szczęście nie trzeba byłoby stawiać tego pomnika? Czy raczej wręcz przeciwnie - gdyby takich żołnierzy było więcej, gdyby większość polskiego wojska w Grudniu 1970 i Grudniu 1981 odmówiła wyjścia z koszar, tak jak odmówili wyjścia z koszar żołnierze armii czechosłowackiej w czasie Praskiej Wiosny 1968 roku, w Gdańsku zabitych byłoby tysiąc razy więcej, bo sprawę w swoje ręce wzięłaby Armia Czerwona i trzeba by było potem postawić w całej Polsce takich pomników jak ten, który stoi tam, przed byłą bramą stoczni, parędziesiąt albo paręset?
Ten pomnik ma kilka tajemnic, o których napisałem książkę. Jakie to tajemnice? Prymas Tysiąclecia Stefan Wyszyński nie chciał, by pomnik nazywał się tak, jak nazywa się dzisiaj, to znaczy pomnik Poległych Stoczniowców. Chciał, by nazywał się pomnik Ofiar Grudnia 1970 - ofiar po obu stronach. I ten pomnik jest $\mathrm{w}$ istocie pomnikiem Ofiar Grudnia, chociaż się tak nie nazywa, o czym nie wie prawie nikt. Na odlanej z brązu tablicy pamiątkowej figuruje napis "Oddali życie, abyś ty mógł żyć godnie", ale wśród nazwisk tych, którzy oddali życie, abyśmy mogli żyć godnie, widnieje nazwisko zomowca, Mariana Zamroczyńskiego, który najpierw zabił strzałem z pistoletu jednego z demonstrantów, a potem został podobno żywcem rozszarpany na strzępy przez demonstrujących stoczniowców przed gdańską komendą milicji na Kartuskiej. I tak powinno pozostać. Ten pomnik jest nie tylko pomnikiem chwały poległych, lecz także pomnikiem ironii polskich dziejów, chociaż prawie nikt $\mathrm{z}$ odwiedzających ten pomnik tego nie wie. I tak powinno pozostać.

I jeszcze jedno. Na murze, który należy do pomnika, widnieje tablica ku czci braci Kowalczyków, którzy z powodów patriotycznych podłożyli bombę pod aulę szkoły wyższej (dzisiaj takich ludzi nazywamy terrorystami) - tablica całkowicie sprzeczna z duchem cytatu z Biblii w przekładzie Czesława Miłosza, znajdującego się na tym samym murze parę metrów dalej, bo pochwalająca przemoc i dynamit w słusznej sprawie. Ale to także powinno tak pozostać. Niczego nie trzeba tu zmieniać. Ta kakofonia znaczeniowa sprawia, że jako pomnik ironii polskich dziejów jest to być może najważniejszy pomnik Polski drugiej połowy XX wieku.

Oddali życie, abyś ty mógł żyć godnie?... Ach, żeby to tak było na tym świecie, jak mówią te słowa odlane w brązie. Że oni - zabici w Grudniu - mogą dzisiaj leżeć spokojnie tam, pod ziemią, bo dzięki temu, że zginęli, my możemy teraz sobie żyć godnie. Bardzo to są gładkie i wygodne słowa. Widzicie - tak moglibyśmy powiedzieć do nich, gdyby oni wstali teraz ze swoich grobów i weszli do tej sali, 
w której mówię te słowa: Nie umarliście na darmo, bo dzięki wam Polska jest niepodległa. Ach, żeby był taki prosty związek między śmiercią zabitych ludzi a biegiem historii.

Bo czy rzeczywiście Polska jest dzisiaj niepodległa dlatego, że oni oddali życie? Politycy chętnie tak mówią, a nauczyciele jeszcze chętniej to powtarzają. My, politycy polscy, jesteśmy spadkobiercami tych, którzy oddali życie za Polskę, my wywalczyliśmy wolność, o którą oni walczyli. A oni? Oni wyszli z domu, pojechali do pracy i zostali zastrzeleni przed bramą stoczni. Jaki był pożytek $z$ ich śmierci i dla kogo? Że ta śmierć podtrzymała ducha w narodzie? Ta śmierć wznieciła przede wszystkim przerażenie - pamiętam dobrze, jak to przerażenie przeszło dreszczem przez całe miasto. Że państwo polskie zabija ludzi na ulicach. Ale to właśnie dzięki tej śmierci - tak, dzięki tej śmierci zwyciężył Sierpień 1980 roku, ale zwyciężył właśnie dlatego, że tę śmierć odrzucił. Wałęsa rozumował słusznie: Nie wolno dopuścić do takiej bohaterskiej śmierci, jak ta w Grudniu, nie wolno wychodzić poza bramy stoczni na ulice, bo jeśli wyjdziemy, wszystko się powtórzy. Gorzki paradoks polskiej historii polegał na tym, że Sierpień 1980 uczcił poległych budową pomnika, ale nie chciał naśladować tych, dla których ten pomnik zbudował. I właśnie dlatego zwyciężył. Czy może istnieć bardziej bolesny paradoks polskiej historii?

A później? Czy ta grudniowa śmierć wpłynęła na to, że Polska jest dzisiaj wolna i niepodległa? 0 , jakiż byłby piękny ten świat, gdyby związek między śmiercią zabitych ludzi a biegiem historii był tak prosty. Wyobraźcie sobie Państwo: jest 14 sierpnia 1980 roku, w stoczni wybucha strajk, ale na Kremlu w Moskwie nie urzęduje żaden zgrzybiały Breżniew, żaden zgrzybiały Andropow, żaden zgrzybiały Czernienko, tylko młody, energiczny, wysportowany specjalista od walk judo, Władimir Władimirowicz Putin. Myślicie Państwo, że on by dał nam czas na jakąś Solidarność? Nie czekałby nawet dwóch dni. Walnąłby żelazną pięścią, a strajkującą stocznię spacyfikował przy użyciu Specnazu w ciągu dwunastu minut. Że nie ośmieliłby się? Przecież zrobił to na oczach całego świata z Gruzją i Czeczenią, a teraz robi to $z$ Ukrainą i Syrią. Wtedy moglibyśmy mieć sto milionów ludzi w Solidarności i nic by z tego nie wyszło.

Wygraliśmy w Sierpniu nie tylko dlatego, że w zimowe dni Grudnia 1970 zginęło czterdziestu paru ludzi, i nie tylko dlatego, że w Sierpniu było nas dziesięć milionów, lecz także dlatego, że afgańscy muzułmanie wciągnęli Rosję w beznadziejną wojnę na Bliskim Wschodzie. To afgańskim muzułmanom w części zawdzięczamy tamto zwycięstwo, bo gdyby oni w 1980 roku nie wciągnęli Rosji w beznadzieją wojnę, sto tysięcy żołnierzy radzieckich nie pojechałoby do żadnego Afganistanu, tylko w naszą stronę i dołączyło do tych, którzy siedzieli od dawna w Legnicy i Bornym Sulinowie. A dzisiaj tych afgańskich muzułmanów Europa chce odpędzić od swoich granic, a i my chętnie byśmy zrobili $z$ nimi to samo.

Lecz może właśnie dlatego, że śmierć tych czterdziestu paru była nadaremna i zarazem nienadaremna, trzeba o niej tym mocniej rozmyślać? Kierowali się odruchem zbuntowanego serca, nierozsądnym odruchem rozpaczy i niezgody na świat, nie wiedzieli jeszcze, jak można walczyć z komunizmem skutecznie, nie mieli jeszcze tej wiedzy, ale kto z nas wtedy wiedział, jak walczyć z komunizmem skutecznie, bo czyż większość z nas nie uważała, że komunizm jest wieczny i za naszego życia nie padnie? Poszli za odruchem serca, wyszli za bramę i dlatego zginęli.

Ale gdyby teraz oni wyszli ze swoich grobów i stanęli pod tym pomnikiem, i rozejrzeli się wokót siebie, czy zapytaliby ze zdumieniem: Gdzie jest nasza stocznia, której oddaliśmy tyle lat naszego życia? I gdzie możemy znaleźć teraz pracę?

I czy naród polski poszedł ich śladami? Ten naród w większości co cztery lata szedł posłusznie do urn wyborczych i wrzucał kartki w socjalistycznej komedii wyborów. Nawet jeśli komuniści fałszowali wyniki tych wyborów, dobrze pamiętam, jak niemal wszyscy sąsiedzi - "zwykli ludzie” z mojej ulicy - 
stawiali się posłusznie w punktach wyborczych, bo - jak mówili - po co się niepotrzebnie narażać, skoro i tak niczego to nie zmieni. Z tego narodu w najważniejszych dla dwudziestowiecznej historii Polski wyborach roku 1989 nie poszło do urn czterdzieści procent „zwykłych ludzi” uprawnionych do głosowania, a w drugiej turze siedemdziesiąt pięć procent. A na niedawne wybory nie poszło prawie pięćdziesiąt procent, prawie połowa Polaków, tak jakby "zwykli ludzie" chcieli powiedzieć: Nic nas to nie obchodzi, czy w Polsce rządzą ci czy tamci, nic nas to nie obchodzi, my zawsze będziemy mieli takie same kłopoty, my zawsze będziemy na dole, czy w komunizmie, czy w kapitalizmie, my walczymy o życie, o pracę, o mieszkanie, nic nas nie obchodzi, czy rządzą ci, czy tamci, "lewica”, "liberałowie" czy „prawdziwi patrioci”, nie chcemy się w nic mieszać, nie chcemy zabierać głosu w żadnej sprawie, chcemy - niewidoczni - pracować na życie, wychować dzieci i nic więcej.

Więc podziwiam i współczuję tym, którzy byli garstką zdolną głośno powiedzieć "nie". Którzy byli i są zawsze w mniejszości. Tych, którzy wzniecali strajk w Grudniu, którzy organizowali Wolne Związki Zawodowe, kiedy prawie nikt nie myślał o żadnych wolnych związkach zawodowych, którzy broniąc robotników, trafiali na czterdzieści osiem godzin, ryzykując utratą pracy i pobiciem. Ale gorzki paradoks historii polega na tym, że oni tylko w części wpłynęli na bieg dziejów, na to, że dzisiaj jesteśmy wolni i niepodlegli. Prawdziwym darem Boga dla nas i świata był nie tylko Jan Paweł II i jego słynne słowa: "Niech zstąpi Duch Twój i odnowi oblicze ziemi, tej ziemi". Prawdziwym darem Boga, o czym chętnie nie chcemy pamiętać, było pojawienie się na ziemi kogoś takiego jak Gorbaczow, który jest dzisiaj powszechnie znienawidzony w Rosji, bo gdyby go nie było, gdyby on się nie pojawit, moglibyśmy mieć sto milionów ludzi w Solidarności, a nic by nie drgnęło do dzisiaj.

Byłoby bezdusznością wyrzucać narodowi, że zachowywał się tak, jak się zachowywał, bo tak jak większość Polaków zachowuje się większość ludzi na całym świecie. Ci nieliczni, którzy się buntują, są wiecznym wyrzutem sumienia społeczeństw, swoją śmiercią przypominając o powinnościach, o których naród przypomina sobie czasem podczas świąt i rocznic. Ale gdyby wszyscy Polacy byli tacy jak powstańcy listopadowi, jak powstańcy styczniowi, jak powstańcy warszawscy, jak żołnierze wyklęci, jak zabici w Grudniu, gdyby wszyscy Polacy byli tacy, jak rotmistrz Pilecki, Polski by już na mapie nie było, a nas nie byłoby teraz w tej sali, bo pośrodku Europy, między Bałtykiem a Tatrami, stałoby tylko jezioro polskiej krwi. Warunkiem naszego narodowego istnienia były dwa skrzydła polskiego ducha: przejmujący głos garstki poległych i bierna uległość milionów „zwykłych ludzi”, których codzienna Ewangelia brzmiała: jak zobaczysz tłum, szybko wracaj do domu, nie mieszaj się w nic, nie narażaj się niepotrzebnie, weź wodę w usta, idź posłusznie do pracy, żebyś miał za co utrzymać żonę i dzieci. Fundamentem naszej niepodległości był krzyk garstki poległych i bierność milionów „zwykłych Polaków” - dzięki której właśnie przetrwaliśmy, codzienna bierność milionów wobec każdej władzy, obojętne, jaka by ta władza była, codzienna strategia przeczekiwania złych dni, czekania, aż los się odmieni.

I ten pomnik jest dla nas takim wyrzutem sumienia, bo my żyjemy i możemy się cieszyć wolnością dlatego, że nie byliśmy podobni do nich, do tych, którzy w Grudniu zginęli. Że ocaliło nas i naszych rodziców od śmierci właśnie to niepodobieństwo.

Oni są dla nas wygodnym symbolem, byśmy $z$ jego pomocą mogli załatwiać swoje bieżące sprawy. Byśmy mogli sobie wygłaszać dumne przemówienia, nieść sztandary, urządzać uroczystości z toastami. Mają swoją śmiercią oskarżać komunę i symbolizować drogę Polaków do wolności. A oni nie byli żadnymi gwiazdami walki o wolność. Ich nazwisk nie ma w żadnych podręcznikach. Dla większości Polaków - i dla świata - to jacyś anonimowi ludzie, zabici kiedyś w Gdańsku. I żaden pomnik tego nie zmieni, chociaż dobrze się stało, że ten pomnik został tutaj wzniesiony. 
Dlatego nie chciałbym, by oni stali się bohaterami Krainy Szlachetnego Patriotycznego Kłamstwa, bo kłamstwo, jak mówił nam Jan Paweł II, nawet jeśli jest to Szlachetne Kłamstwo Patriotyczne, które ma wzmacniać naszą dumę narodową, nigdy nie przynosi dobrych owoców. Krzyk tej garstki poległych, który rozległ się w Grudniu, miał wielkie znaczenie dla naszej zbiorowej duszy, ale nie wolno też jego znaczenia przeceniać, bo to nierozsądne i niebezpieczne dla zbiorowego rozumu. Tak jak nie wolno pomniejszać roli żołnierzy wyklętych, pamiętając równocześnie, że oni zostali zmiażdżeni nie tylko dlatego, że mieli przeciw sobie potęgę komunistycznych sił bezpieczeństwa, ale także dlatego, że w latach czterdziestych odwróciła się od nich większość Polaków, która wybrała tak zwane normalne życie $\mathrm{w}$ realnym socjalizmie. Obok jasnego awersu historia ma zawsze swój ciemny rewers, o którym warto pamiętać, żeby twardo stąpać po ziemi. Co myśleli na przykład wtedy, w Grudniu, mieszkańcy Trójmiasta i mieszkańcy innych polskich miast o tym, co się działo w Gdańsku i na Wybrzeżu? Czy podziwiali zabitych przed bramą stoczni, czcili ich, szanowali, czy też kładąc kwiaty na grobach, dorzucali po cichu: Boże, całe szczęście, że nie było nas wtedy tam, pod stocznią. Bo większość „zwykłych ludzi” jest zawsze taka sama: czci, stawia pomniki, składa kwiaty, a równocześnie po cichu lekceważy tych, którzy - jak z bolesną ironią pisał kiedyś Tadeusz Borowski - dali się zabić. Bo żywi są zawsze przeciwko umarłym. I robią z nimi - zupełnie bezbronnymi - co chcą, stosownie do własnych potrzeb.

Więc pamiętając o Grudniu, powinniśmy stać też na straży prawdy, która jest zawsze niewygodna, zagmatwana i bolesna, jeśli rzeczywiście chce być prawdą. Bardziej rozmyślać nad tym, co stało się w Grudniu, by zrozumieć głębiej nasz polski los, niż świętować w huku bębna i trąb orkiestry. I nieść w sercu pamięć o tych, którzy stracili życie, a przede wszystkim darzyć współczuciem dotknięte bólem rodziny, które z całą pewnością wolałyby, żeby oni żyli do dzisiaj i byli tutaj, wśród nas.

Gdańsk, 16 grudnia 2015 